\title{
CONSTRUÇÃO E DESCONSTRUÇÃO NO DISCURSO DE ALGUNS ESTRANGEIROS DO SÉCULO XIX
}

\author{
Helenice Maria Reis Rocha \\ Universidade Federal de Minas Gerais
}

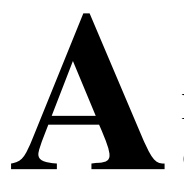

percepção que configura o olhar do estrangeiro do séc. XIX sobre a nação brasileira se defronta, não com um outro, perfilado na frente deste estrang eiro como única possibilidade de diferença mas com vários outros, tendo-se em conta a diversidade cultural brasileira. Em razão desse nosso bailado de culturas teremos que facetar este olhar com várias diferenças. No entanto, o viajante europeu vem informado por alguns parâmetros que lhe norteiam uma visão de mundo mais ou menos delimitada, face à diversidade cultural que encontra. A tentativa deste trabalho é a de encontrar o discurso deste estrangeiro na sua condição de estratégia de enunciação. Menos do que reflexões sobre a sua estrutura lingüística, ou sobre a sua estrutura narrativa, coisas que nos colocariam no parâmetro do enunciado, a intenção é a de avaliar as condições de produção deste discurso, tendo em vista o contexto, qual seja, a quem se dirige, de que lugar ele se origina e a que lugar ele se destina, categorias básicas da Análise do Discurso. É o caso de se pensar quem é este europeu que percorre o Brasil do séc. XIX. De que topos cultural ele enuncia, a que lugar na cultura ele se dirige, e qual é a identidade da sua enunciação. Neste sentido, tratase menos de fazer uma análise sociológica deste estrangeiro, do que perceber este topos através do seu discurso.

Através da análise crítica da sua fala, das suas posições, esse topos vai se explicitando naturalmente. Na realidade, talvez seja o caso da configuração não de um discurso, mas de pelo menos dois. Aquele que emerge do homem europeu do séc. XIX e o que nasce 
da experiência de observação e viagem. Neste sentido uma idéia pode ser apreendida: a que versa sobre a natureza humana (a idéia da imanência da bondade humana, de Rousseau, da qual derivam a idéia do homem cordial e a do bom selvagem).

Todo o discurso do estrangeiro do século XIX é informado, talvez pelo princípio da bondade humana inscrito nas construções sobre o que significa homem civilizado e civilização. Neste sentido, a idéia recorrente da hospitalidade do homem brasileiro é uma derivação destas construções. A noção de uma natureza paradisíaca é também uma construção do homem europeu, com relação ao chamado Mundo Novo e pode ser também uma derivação do ideário de Rousseau. Em relação a estes três construtos: a idéia do lugar paradisíaco, do bom selvagem e do homem cordial, já se pode estabelecer um choque cultural entre uma nação "bárbara" e o mundo "civilizado" do qual estes europeus emergem. Tentar-se-á, neste trabalho, estabelecer a especificidade deste discurso no que diz respeito ao africano, ao indígena e ao português. Este discurso caminha por uma tentativa de ajustar o homem encontrado nos trópicos aos padrões culturais europeus, no sentido de torná-lo útil às necessidades e desejos deste estrangeiro. Assim sendo todo esse construto ideológico visa à configuração de um nativo dócil à esse desejo. Ainda nesta linha, a cordialidade, a hospitalidade, a gentileza, visam a este fim. Esta posição configura o não dito da experiência linguageira, resgatável justamente através da Análise do Discurso. Vejamos alguns exemplos da idéia do homem cordial:

Nossos hospedeiros eram um próspero, e portanto industrioso casal de negros (...). A casa, construída apenas de adobe à vista, sem caiação ou pintura, tinha no entanto uma aparência limpa e confortável; e os negros se mostravam excelentes anfitriões, fazendo o que podiam para nos agradar e prestando inteligente atenção aos nossos pedidos de que se usasse um mínimo de gordura e nenhum alho no preparo do jantar, mais tarde, nos serviram um ótimo jantarzinho da roça, pacientemente aguardado e devidamente apreciado. ${ }^{1}$

${ }^{1}$ WELLS, 1995. p.95. 
Observemos a frase: “... excelentes anfitriões, fazendo o que podiam para nos agradar..." ou seja, o elogio da cordialidade, da hospitalidade, não é um valor em si, mas um valor em função da satisfação de desejos exigentes ... "um mínimo de gordura e nenhum alho no preparo do jantar.” Repare-se na expressão “... atenção inteligente...". Como sempre, no que diz respeito aos afro-brasileiros, vida inteligente vem sempre associada ao ato de servir. Vejamos mais alguns exemplos desta idéia da hospitalidade brasileira:

Mas meu anfitrião e sua esposa eram na verdade pessoas muito bondosas, que faziam o que podiam para satisfazer os meus desejos tanto relativos à acomodações quanto à comida, e eu realmente não tinha do que me queixar; eles me forneciam um suprimento generoso e variedade de comestíveis, com abundantes legumes e verduras nativos. ${ }^{2}$

Na verdade, todo o discurso do estrangeiro vem informado pela instância do desejo, no caso desejo de ser bem servido, e é perpassado pelo mundo real como uma cirurgia, que deixa marca mas que não mata, na medida em que se flexibilizam posições e atitudes o tempo todo, bem dentro de uma linha dialética que relativiza valores e convicções. Todavia, em relação à hospitalidade, o modelo europeu é sempre imanente à experiência real sobrepujando a experiência vivida e construindo um imaginário que remete à memória ou à busca da referência original no presente. Numa dimensão de um imaginário que perpassa todo o enunciado o europeu diz:

Onde quer que se encontre o brasileiro, é sempre cortês e raramente não é hospitaleiro, especialmente nas zonas menos freqüentadas do país.

É muito mais moderado no beber que no comer e muito dado ao uso do rapé e do fumo... ${ }^{3}$

2 WELLS, 1995. p.137.

${ }^{3}$ GARDNER, 1975. p.23. 
Ao longo da experiência de viagem esta linguagem muda, refletindo uma outra visão do homem brasileiro que configura uma construção discursiva que se opõe a esta idealização. Este homem, quando não é visto como hospitaleiro, é considerado preguiçoso, indolente, fanfarrão e até criminoso. Vejamos a construção linguageira que cerca este tipo de brasileiro:

Indagamos onde poderíamos descansar, e nos indicaram uma espécie de rancho deserto, verde pela decomposição, imagem viva do perigo de febres. Um certo José Antônio de Azevedo logo se revelou uma boa bisca 'o perfeito salafrário avarento e insolente, o modelo da falta de educação, resmunguento e de capacidade inescrupulosa. Esse velho bruxo nos espantou. O viajante, nestas terras, torna-se tão acostumado com a amabilidade e a hospitalidade dos brasileiros, que sente vivamente as pequenas manifestações de incivilidade, que the passariam despercebido na França ou na Inglaterra. E quanto é rara aqui a falta de educação se pode avaliar pelo fato de ter sido esse Azevedo a única e lamentável exceção dessa regra de delicadeza e boa vontade. ${ }^{4}$

Nesta passagem, percebemos através da linguagem usada a desconstrução da idéia de paraíso tropical e a reafirmação da idéia do homem cordial.

No caso em questão, trata-se de uma exceção. Já podemos observar a incidência deste construto em pelo menos três viajantes: Gardner, Wells e Burton. A informação contextual que os situa é o desejo de serem bem servidos e o que marca esta relação não é um entendimento entre as partes mas uma confrontação de desiguais na qual o estrangeiro ocupa uma hierarquia superior. Esta desigualdade se refletirá na construção discursiva, informando o rumo deste discurso e a construção dos relatos. Nestes se entrevê a idéia que o estrangeiro faz de si e do outro, em que lugar se coloca e em que lugar situa o outro na hierarquia cultural. Voltando à questão da idéia do brasileiro cordial, hospitaleiro, observe-se a seguinte passagem:

${ }^{4}$ BURTON, 1976. p.147. 
Passamos por um rancho, cujo dono, alto e barbado, com um chapéu de abas caído sobre os olhos, olhou-nos grosseiramente, e não respondeu às perguntas que lhe fizemos sobre a possibilidade de nos conceder hospedagem durante a noite. Esse indivíduo, chamado João Militão, tem fama de ser valentão, ou pior ainda, "capanga", assassino profissional. Estes capangas, relíquia dos tempos bárbaros, infelizmente ainda não desapareceram no interior das províncias brasileiras. Como a honra continua a ser uma inspiradora de ação, e o duelo é desconhecido, os ofendidos recorrem aos serviços de facínoras mercenários, e o inimigo é alvejado de trás de uma árvore, como o proprietário rural irlandês da geração passada. ${ }^{5}$

Aqui é interessante observar como a experiência discursiva constrói o real, na medida em que o mesmo autor que considera a descortesia uma exceção no homem brasileiro, nos confronta com o tão conhecido pistoleiro profissional. Esta confrontação entre real e imaginário aponta para o fato de a linguagem, como construção abstrata, trair o estatuto da verdade e aterrizar comodamente no inventado, se pensarmos que ela não apenas veicula valores, mas os constrói e inventa. A linguagem humana é, neste sentido, uma caminhada em direção à perda, ao desperdício do vivido. Neste sentido é que se deve entender o esforço de Sir. Burton no objetivo de reforçar a tese da cordialidade e hospitalidade brasileira, valor que se sustenta na experiência linguageira do discurso e que não tem procedência no real. É interessante observar a desconstrução discursiva destas idéias nos próprios construtos do estrangeiro, colocando em circulação, num mesmo contexto, informações contraditórias. Com relação à idéia do homem cordial, o discurso do estrangeiro constrói e desconstrói à vontade, sem se importar em dizer e desdizer ao mesmo tempo, ao sabor das circunstâncias e da experiência vivida:

Vejamos o seguinte passo:

"Já passava das 8, mas meus amigos não mostravam sinais de se retirar, exceto por a velha senhora ter estado ocupada no interior do quarto cercado, evidentemente preparando sua cama, pois ouviam-

${ }^{5}$ BURTON, 1976. p.171. 
se os sons de lençóis sendo estendidos. Ela agora volta, o velho lhe pergunta: Está pronto?" e, recebendo uma resposta afirmativa, levanta-se, e com um gesto bondoso informa-me que "quando eu quiser me retirar, a cama está à minha disposição, se é que eu posso aceitar por uma noite a pobre acomodação de um sertanejo. Quando consigo me recuperar da surpresa causada pela oferta dessas boas pessoas de me cederem sua única cama e quarto e recostarem seus corpos idosos sobre um couro de boi nesta atmosfera hibernal, ora, é claro, reuni todos os meus poderes de argumentação para protestar com energia contra tal arranjo e..."

Considerando o relato uma das formas de articulação da experiência discursiva pode-se concluir que o desejo conduz esta experiência na busca de bons exemplos da tese que se quer demonstrar. Entretanto, esta linguagem muda, no momento em que o vivido muda. Talvez fosse o caso até de algumas reflexões sobre a relação entre o vivido e a urdidura linguageira nos casos mencionados. A idéia do homem cordial, repassada da cultura européia, se entremostra na experiência discursiva do estrangeiro como uma instância do desejo que é reconstruída e desconstruída na linguagem, de acordo com a experiência vivida. Vejamos agora, um momento de desconstrução que nos entremostra um outro tipo de homem brasileiro, nem tão gentil, nem tão cortês como se quer:

Mas todos esses homens tão jovialmente ocupados tinham reputações sinistras, pelo menos aqueles acerca dos quais pudemos obter alguma informação; ao Adônis, especialmente, eram atribuídas várias mortes, resultados de lutas livres; ele era procurado pela polícia e já tinham tentado prendê-lo. Dizem que em uma ocasião a polícia cercou uma casinha de pau-a-pique em que ele dormia; mas tendo sido prevenido a tempo, ele levantou barricadas nas portas e janela, e enquanto a polícia arrombava a porta, fez um buraco através da cobertura de capim, escorregou de lá, saltando sobre os perplexos policiais como um arlequim, deu-lhes umas facadas como lembrança e desapareceu na floresta. Recusarmo-nos a empregar tal homem seria simplesmente absurdo; ele não era pior

${ }^{6}$ WELLS, 1995. p.162. 
do que qualquer outro que pudéssemos encontrar, esplêndido homem do mato e, mais estranho ainda, aparentemente honesto e confiável e, julgando-se o seu caráter de um ponto de vista nacional, não era pior que nenhum valentão de aldeia inglês." ${ }^{7}$

Ou seja; o pior assassino e bandido é ótimo, se servir aos propósitos de viagem. Todo o discurso sobre o bem e o mal, em relatos de estrangeiros é flexibilizado pelos ditames do interesse.

Nos outros relatos (Gardner, Eshwege, Burton, Wells ... etc.) o senso moral do viajante é mediatizado pelo interesse em questão. São muitos os exemplos e fugiria ao escopo deste trabalho enumerálos todos. Mas já se pode perceber uma das trilhas desta reflexão, qual seja: os reflexos no discurso do viajante da construção e desconstrução das muitas visões da cultura européia com relação às experiências de viagem. Uma outra reflexão seria a da dimensão imaginária da experiência discursiva do viajante estrangeiro e da sua relação com o real. É provável que a idéia da imanência da bondade humana, de Rousseau, tenha se estendido, no imaginário do homem europeu, a toda a idéia da natureza que se tinha então. Neste sentido, o homem é naturalmente bom, e a natureza, como reflexo desta bondade é um paraíso a serviço desse homem. Por essa razão, este construto de mundo paradisíaco que norteia os discursos sobre a natureza dos mundos descobertos só foi desmontado na experiência viageira. A idéia de um locus amoenus era de fundamental importância para a coroa portuguesa, pelo menos no sentido de que se conseguisse gente para arriscar o corpo e a alma em terras estranhas. Ao fim de sua experiência Wells fala até em pesadelo. No século XIX, esta visão do paraíso já está desconstruída, mas sobrevive no êxtase do contato real que toda experiência com a natureza provoca. E sobrevive na experiência discursiva como um conflito que se expressa mais ou menos nos seguintes termos: paraíso ou inferno? Terra de promissão ou de danação? Em Burton, a beleza tropical adquire até uma dimensão ontológica em termos de Bem e Mal; Vejamos alguns exemplos, começando pelo próprio Burton:

7 WELLS, 1995. p.171. 
E não será a beleza a forma visível do Bem? Como estas páginas mostrarão, uma viagem à terra do pau-brasil não se parece com uma viagem a qualquer outra terra. Há uma gentileza, uma amenidade de aspecto, que os filhos do austero Norte vêem pela primeira vez, e que devem esperar jamais ver de novo. Ao mesmo tempo, encontraremos entre o povo pronunciados traços de caráter e uma energia quase selvagem, que se faz sentir dos ossos à flor da pele. ${ }^{8}$

Esta projeção de características morais na natureza e a conseqüente projeção da natureza no homem funciona no mesmo sentido da metafísica de Rousseau que acredita ser o homem produto do meio. Neste sentido, produto do meio natural. A idéia de um lugar ameno é refletida no discurso do europeu através de uma linguagem que espelha, às vezes, o suave, o sublime, e outras vezes o terrível, o maravilhoso. Vejamos alguns exemplos:

A "Baía do Rio", como suas belas irmãs, desde a "Mullions" da Cornualha até a Baía de Nápoles, deve ser vista em trajes de gala! É mais encantadora quando se estende sob seu rico dossel etéreo, enquanto um verniz de atmosfera diáfana imprime às distâncias uma suave e maravilhosa beleza; quando o manto azul é de um azul perfeito, brilhante, quando as tonalidade castanhas são riscadas de cor-de-rosa e vermelho, e quando as próprias cores nacionais se fazem lembrar: verde, vivo como o da esmeralda, e amarelo, reluzente como ouro brunido.?

Esta projeção do que é da ordem da natureza, na cultura, no nível simbólico faz supor um idealismo que conjuga de forma arbitrária o que é formal (o nível simbólico) e o que é escatológico (o nível da natureza).

O conflito, no nível do discurso é expresso pela negação do olhar, por mecanismos de defesa que reafirmam um mundo idílico, talvez universo do desejo inconsciente de todo ser humano. Vejamos um exemplo:

${ }^{8}$ BURTON, 1976. p.36.

${ }^{9}$ BURTON, 1976. p.36. 
Há, contudo, ocasiões e temporadas em que a Baía do Rio, a Feiticeira, apresenta uma fisionomia perigosamente tempestuosa, para a qual não convém muito olhar. ${ }^{10}$

Vejamos agora a reincidência deste discurso em outros viajantes:

As belezas admiráveis da baía prendiam a atenção do viajante e despertavam a admiração do espectador, oferecendo matéria para o mais agradável divertimento.

No primeiro plano, grandes ilhas dotadas de grandes edifícios e moradias menores, em meio a palmeiras, verdadeiras chácaras atraentes, tão românticas que só um poeta poderia descrevê-las. (...) Todos esses quadros naturais ou de construção humana despertamnos um sentimento singular e agradável, para o qual não existem palavras. Apenas somos capazes de murmurar: Que beleza! Que magnífico! ${ }^{11}$

Esta recorrência ao magnificente, ao sublime, ao maravilhoso é comum nos discursos do europeu sobre a natureza e é também uma projeção do desejo natural do homem que aspira sempre à cosmogonia, à ordem. Todavia já demos uma pincelada no sentido de demonstrar como o conflito homem, cultura, natureza se manifesta no discurso.

Vejamos mais exemplos desta busca do paradisíaco nos relatos.

Não preciso dizer que nada pode ser mais puro do que o ar perfumado destes campos; sua animação combate até a monotonia de uma viagem em lombo de burro, e o viajante europeu nos trópicos recupera neles todas as suas energias, mentais e físicas. As manhãs e o anoitecer são a perfeição em termos de clima; as noites são frias, limpas e serenas como no Deserto Árabe, sem a areia. Nem são as campinas deficientes nas mais elevadas belezas de forma e colorido. Há grandeza e vastidão contínua que se estende e desaparece na distância. O olhar pode repousar sobre o cenário por horas, especialmente quando o observa de uma elevação, enxadrezada pelas nuvens da tarde, cujo eclipse parece ir e vir, e

${ }^{10}$ BURTON, 1976. p.36.

${ }^{11}$ ESCHWEGE, 1996. p.57. 
isto dá mobilidade ao conjunto, ao vagar pela superfície sulcada das ondas de terra verde-clara ou dourado-pálido, erguidas na atmosfera intensamente azul da manhã, ou arrebol, das ravinas emsombrecidas e dos grupos de árvores que escurecem lá embaixo. ${ }^{12}$

O mesmo Wells cita Mr. Bigg-Witther na mesma página. Vejamos:

Ó, Deuses! Como meu coração saltava-me no peito à vista há tanto esquecida das grandes planícies ondulantes, estendendo-se sem fim até o horizonte indistinto, até os próprios limites do paraíso. $\mathrm{Na}$ excitação e entusiasmo do momento, abandonei a trilha e galopei para o topo da crista de onda mais próxima, e lá permaneci pelo espaço de cinco minutos completos, com o peito dilatado e os braços abertos, inalando sobre os campos vindas diretamente do Atlântico. Sentiame como uma prisioneiro acabado de ser libertado de seu calabouço. Por trinta meses eu não soubera o que era sentir um sopro de ar em minha face - nem enxergar mais além do que minha voz podia alcançar. Gritei de alegria, de modo que meus ajudantes, Pedro e Messeno, pensaram que eu tinha enlouquecido de repente. ${ }^{13}$

Vê-se que a noção do paradisíaco, nestes relatos, já vem tisnada pela associação da beleza com algo de terrível, enlouquecedor, o que coloca a recorrência a esta tema, no discurso do viajante, num lugar de fronteira. Em Wells, por exemplo, observase a passagem da idéia de um locus amoenus para a de um locus horrendus que muda a direção da linguagem. Pode-se perceber nestes relatos que esta relação é intermediada pela cultura, já que a incidência do desejo da ordem, da cosmogonia nesta natureza se inscreve no nível do simbólico que é marca cultural do homem. Alguns exemplos desta transição do ameno para o horrível nos construtos de Wells, reproduzindo o positivo e o negativo do discurso, marcam a ambigüidade da narrativa que versa sobre o meio ambiente, assinalando flutuações expressivas. No passo que se segue Wells descreve um lugar agradável, apelando para o maravilhoso e sublime:

${ }^{12}$ BURTON, apud WELLS, 1995. p.154.

${ }^{13}$ BIGG - WITTHER apud WELLS, 1996. p.154. 
À medida que progredimos pela floresta, cruzamos muitos arroios de água maravilhosamente límpida e fria, que deslizam sobre pedras limosas e entre margens de delicadas samambaias, vindos dos regos da encosta íngreme. Às vezes temos de escalar os esporões pedregosos e abruptos das montanhas, ou executar proezas ginásticas, engatinhando ao longo de ou sob os penhascos acidentados, quase sempre suspensos sobre o rio. ${ }^{14}$

Ou seja: nesta construção discursiva já se nota a transição da amenidade para uma certa margem de desconforto. Vejamos mais alguns exemplos desta transição:

Mas estes rios goianos, especialmente os destes gerais, têm a fama de serem tão bem providos de habitantes estranhos e venenosos, que não se pode evitar um sentimento de apreensão ao dar um mergulho, pois há jacarés, enguias elétricas, piranhas e, finalmente, uma certa aranha d'água, que eu tenho estado curioso para ver, mas ainda não consegui; de acordo com as descrições, é uma espécie de raia-lixa, que freqüenta os fundos dos rios junto à margem, e quem quer que pise nela, pisa em um longo espinho que se projeta a várias polegadas de perto da extremidade de sua cauda; a ferida causa grande agonia e muitas vezes paralisia parcial da perna. ${ }^{15}$

Como se percebe, nesta descrição já se introduz uma parcela de estranhamento e dor, no discurso sobre a relação homem-natureza. Vejamos agora exemplos de uma construção discursiva diferente:

Mas à medida que avançamos, vamo-nos metendo em terríveis enrascadas, primeiro trombamos com três troncos submersos, livramo-nos dos dois primeiros com certa dificuldade, mas da terceira vez ficamos entalados firmemente na forquilha de uma árvore submersa, e os homens estão com tanto medo das piranhas (e com razão) que não querem se aventurar na água e têm de por-se a trabalhar para serrar e cortar com machadadas o obstáculo; subitamente eles nos assustam com fortes exclamações e maldições generalizadas, e quando vamos ver qual é o problema, descobrimos

${ }^{14}$ WELLS, 1995. p.137.

15 WELLS, 1995. p.142. 
logo, pois temos a bordo um enxame de formigas grandes e pretas, que os homens a princípio intitulam unanimemente "formigas do diabo" e realmente eles não estão longe da verdade, pois estas são as terríveis "formigas de fogo", cujas picadas venenosas são como uma queimadura grave. ${ }^{6}$

Através deste relato, pode-se resgatar o não-dito nos seguintes termos: "esta natureza é infernal, estamos longe do paraíso isso é um pesadelo ... etc." Wells finaliza a sua 'impressão do paraíso' com as seguintes palavras:

Iniciei minhas viagens cheio de entusiasmo e deleite diante da perspectiva de "uma vida rústica" nos distantes ermos pouco conhecidos, mas terminei-as com um prazer muito maior e um sentimento grato de alívio, como se tivesse acordado de um pesadelo. ${ }^{17}$

Esta guinada na construção do discurso, que caminha na direção oposta à premissa básica é observável também em Eschwege, Burton e Gardner. Vejamos alguns exemplos:

Nos pântano deste vale costuma se encontrar a boa constrictor, às vezes de considerável tamanho; não é rara em toda a província, especialmente nas margens dos lagos, pauis e regatos cercados de árvores. Atingem às vezes, o enorme comprimento de quarenta pés: a maior que já vi, encontrei-a neste lugar: mas não estava viva. (...) Abrindo-a, encontraram-se dentro dela os ossos meio quebrados de um cavalo, com a carne em parte digerida, mas os ossos da cabeça intactos. Concluímos daí que a boa devorara o cavalo inteiro. ${ }^{18}$

A experiência real desconstrói a idéia de uma América paradisíaca e aponta para uma construção discursiva que, se não desemboca para o seu oposto, caminha nesta direção.

Vejamos mais alguns exemplos:

\footnotetext{
16 WELLS, 1995. p.220.

17 WELLS, 1995. p.239.

${ }^{18}$ GARDNER, 1975. p.165.
} 
De tarde fui banhar-me em um riozinho que corre a pouca distância da casa e, vendo uma planta em flor entre umas moitas da margem, ali entrei para colhê-la; mas verifiquei, ao sair, que tinha pago caro a flor, porque minha camisa e calças, bem como as mãos e pés, estavam repletos de carrapatinhos. ${ }^{19}$

Em Wells fica clara a desconstrução do discurso que versa sobre uma América paradisíaca. Em Gardner, a experiência real, o vivido, modifica os depoimentos sem se configurar entretanto numa desconstrução discursiva. Vejamos um último exemplo:

Na maior parte de Minas e São Paulo, o carrapato domina; parece estar no ar; cada folha de capim tem sua colônia; bolos de centenas se agarram aos gravetos; miríades são encontrados nas moitas de arbustos. ${ }^{20}$

Percebe-se, nestes construtos, a passagem da idéia de Locus amoenus para a idéia de Locus horrendus. No entanto só em Wells esta nova posição fica evidente. A idéia da natureza edênica cede lugar à visão de um inferno tropical que em determinados momentos não deixa nada a dever a Dante.

Passamos pela idéia do homem cordial, pela idéia de um locus amoenus, tentando demonstrar a sua construção e desconstrução no discurso. Um dos construtos mais caros ao mundo europeu é o que versa sobre a idéia do bom selvagem. Esta idéia, derivada da convicção de uma bondade imanente ao homem, é completamente destruída nos relatos dos viajantes. Já vimos que a linguagem nem sempre caminha junto com o real. Neste sentido observa-se que o viajante europeu vem com uma abertura para o imaginário na medida em que idealiza mundos e homens tomando como ponto de partida as ilusões da sua própria cultura. Com relação aos índios, a construção discursiva nos remete a uma realidade dialética. O índio que emerge deste discurso não é nem tão bom nem tão mau quanto se pinta, mas simplesmente mergulhado em suas estratégias de sobrevivência em face aos choques culturais de contato. Todavia,

${ }^{19}$ GARDNER, 1975. p.175.

${ }^{20}$ BURTON, 1976. p.147. 
como a análise destas estratégias de sobrevivência exigiriam um estudo exaustivo, no nosso caso trata-se de abstrair o índio que emerge dos relatos e que discurso o enfoca. Por quem é proferido e a quem serve. Talvez a idéia do bom selvagem esteja ligada à necessidade de submissão característica a todo colonizador. Talvez seja a projeção do desejo do colonizador de não encontrar nenhum obstáculo. Vejamos alguns relatórios:

Os aimorés

Também estes têm sempre causado muitos prejuízos às plantações dos portugueses, principalmente no litoral da capitania de ilhéus, habitada pelos Tupiniquins, que a abandonaram com receio desses selvagens e internaram-se no sertão, onde acamparam em dois sítios da usina de açúcar de Henrique Reis.

Os aimorés são descendentes dos Tapuias (...) Eles são tão indômitos e selvagens, que são respeitados pelos outros selvagens como ferozes animais. Alguns, aprisionados em Porto Seguro e Ilhéus, recusaram todo alimento quando presos e morreram, como numerosos animais selvagens em cativeiro. ${ }^{21}$

No caso deste relato, o indígena é descrito tomando-se como valor de base a sua submissão ou insubmissão e é-lhes tirada até a dimensão humana na medida em que aparecem aí comparados aos animais. Está completamente desmantelada a idéia do bom selvagem. Em algumas das descrições o europeu defende o direito do indígena, tanto quanto o do afro-brasileiro, à sobrevivência, mas quando coloca os termos da relação, a superioridade do branco europeu é considerada natural.

Vejamos outro exemplo:

Os caetés do litoral pernambucano

Sempre estes selvagens, que habitam o litoral entre a margem direita do rio São Francisco e a esquerda do Paraíba, viveram em dissensão com os portugueses. Também travaram uma constante e cruel guerra, em terra e no mar, contra os pitaguaras, degolando-se e devorandose mutuamente...22

${ }^{21}$ ESCHWEGE, 1996. p.239.

${ }^{22}$ ESCHWEGE, 1996. p.239. 
Segue-se uma descrição de batalhas com outras tribos. Sem compreender a lógica indígena, é como se o autor estivesse querendo nos dizer que o índio brasileiro é um caso perdido em termos de sobrevivência devido à sua autofagia. É o caso de pensarmos no sem número de contradições que a civilização contemporânea cala para permanecer intocável. Compreender a lógica guerreira é uma possibilidade distante para o bom europeu, que se considera um cavalheiro escolhido por Deus e pela vida para desfrutar de superioridade moral e econômica.

Todavia, a face mais interessante do relato de Eschwege sobre o indígena, está na sua própria reflexão sobre as diferenças em questão. Vejamos:

O homem, no estado natural, desperta na imaginação um interesse particular. Deve-se acreditar que, onde a lei ou a convivência não regula as paixões dos homens, logo se originam entre eles embaraços e mesmo vínculos familiares se rompem. E contudo não é bem assim. As famílias vivem em concórdia, pacífica e sossegadamente e ninguém parece comandar, cada um obedece igualmente apenas à uma voz interna e misteriosa que lhe recomenda a manutenção da convivência e do bem estar familiar. ${ }^{23}$

O estado de natureza, tão discutido no séc. XVIII, considerado tão perigoso ao homem que exigia a intermediação do estado para a manutenção da ordem, é visto neste relato, como uma surpreendente experiência de cosmogonia, completamente inusitada para os parâmetros de um homem europeu. Todavia, recorre-se à tentativa de impor ao indígena a noção de cidadania do homem branco, europeu, numa repetição mecânica dos mesmos padrões discursivos que marcaram os relatos analisados. O próprio Eschwege nos diz:

Séculos seriam precisos provavelmente para transformá-los em cidadãos, se é que isso fosse possível, do que duvido, pois na própria imutabilidade jaz o fundamento do seu extermínio. Já há dois séculos trabalha-se neste sentido no Brasil; com meios apropriados?

${ }^{23}$ ESCHWEGE, 1996. p.237. 
Isto resta saber. O certo é que numerosas nações, mesmo em conseqüência da civilização, desapareceram completamente, como por exemplo, os goitacás, os paraíbas e numerosos habitantes do litoral. ${ }^{24}$

O discurso fala por si, sem necessidade de uma análise. Ou seja, a sobrevivência do indígena é inviável em face à superioridade da civilização. A diferença é o motivo do fim e o destino do índio é fatalmente desaparecer em face da sua ineficiência natural frente os valores da civilização.

Mas vejamos o enfoque de Gardner:

O número de famílias que habitam a ilha chega a cerca de quarenta e são, em maior parte, índios civilizados. Na tarde de nossa chegada apresentei-me ao seu capitão, homem já idoso, trajando calças de algodão, camisa do mesmo pano, chapéu e sandálias de couro. Estava sentado debaixo de um Liziphus consertando uma rede de pesca. Por ele soube que os índios da ilha estão diminuindo gradativamente de número. Suspirou o velho ao dizer-me que não estava longe o dia em que sua raça estaria extinta ou, pelo menos, mesclada com os outros habitantes.

Os que ainda não se amalgamaram são de pequena estatura e de constituição vigorosa, parecendo ter índole afável e obsequiosa. ${ }^{25}$

Observando o discurso de Gardner; podemos perceber que nem este sentido anúncio do fim fez com que o inglês mudasse o se elogio da cordialidade dos brasileiros. Através da análise dos discursos analisados, os índios do testemunho de Gardner são os mais próximos da idéia do homem cordial trazida pelo estrangeiro e insistentemente projetada na nossa paisagem humana. No entanto, há que se perceber que esse estrangeiro não profere uma única palavra de consternação ou de protesto diante desta pequena crônica de uma morte anunciada. Mais importante do que a sobrevivência do indígena parece ser a sua civilidade.

${ }^{24}$ ESCHWEGE, 1996. p.237.

${ }^{25}$ GARDNER, 1975. p.70. 
Algumas vezes, toda a desconstrução do discurso que versa sobre a amenidade da natureza, sobre a cordialidade do homem brasileiro, emerge em poucas linhas:

De novo, os mosquitos torturam-nos durante toda a noite. De fato, neste grajaú não há como escapar de um tal inferno, dentro da água piranhas e enguias elétricas, na superfície, piuns, formigas e mutucas; e na terra, mosquitos e vespas. Sentia-me arder em febre com a dor e a irritação de tantos suplícios; ... ${ }^{26}$

Vemos, a nível de relato, o desmantelamento completo de qualquer idéia de paraíso. Vejamos como isto se reflete na idéia que se construía na mente de Wells a respeito de sua relação com os índios.

Há também uma mosca sanguissedenta que deixa uma pequena gota de sangue onde lhe permite saciar-se. A gente se sente até um pouco inclinado a desculpar a crueldade dos antigos barqueiros do rio quando atiravam em índios indefesos à margem, pois, sob um tal processo de tortura incessante, cria-se um sentimento e um desejo louco de esmagar ou destruir alguma coisa ou qualquer coisa. ${ }^{27}$

Nesta apoteose do inferno, a natureza humana se torna demoníaca e a tese de Rousseau, segundo a qual "o homem viveu originalmente no estado natural - o qual, (...), ele considerava como um verdadeiro paraíso." (Burns, 1972:602) é subvertida pela confrontação com uma realidade alucinadoramente brutal, que transtorna os parâmetros deste branco europeu transformando-o, que ironia, num selvagem.

Vejamos as reflexões de Eschwege, sobre a diversidade de interesses e as diferenças entre as várias tribos.

Onde, por assim dizer, cada membro de uma nação procede livremente, não nascem poderosas nações: o interesse de cada família é divergente, apesar de os homens serem limitados pela existência. Uns amam essas regiões, outros a caça, estes vivem quase

${ }^{26}$ WELLS, 1995. p.221.

${ }^{27}$ WELLS, 1995. p.221-222. 
exclusivamente de raízes e frutos, aqueles de carnes, outros dão preferência à pesca, e a água é o seu elemento. Por isso, compreende-se facilmente, nas tribos principais, a existência de tantos costumes, usos e línguas que isolam as tribos do Brasil entre si, como acontece na América do Sul. ${ }^{28}$

A forma de se dissimular conflitos sob a capa de civilidade, traduz-se nesta visão de estrategista pelo vício de se considerar a diferença como forma de se perder na existência humana. Foge ao escopo deste trabalho uma reflexão mais acurada sobre as nuances e derivações da cultura indígena, mas acredito, com estas reflexões, ter conseguido elucidar um pouco do sentido do discurso dos viajantes analisados no que diz respeito ao homem indígena.

Com relação ao homem negro, este discurso oscila do repúdio à escravatura ao reconhecimento implícito da superioridade do branco europeu. Em Gardner se apreende uma definição a respeito do que ele considera ser brasileiro:

A população do Rio é formada principalmente de portugueses e seus descendentes, brancos e de cor; só os nascidos no país são chamados brasileiros... ${ }^{29}$

A rigor, na visão de Gardner, o brasileiro é o mestiço. Isto pressupõe a ausência de racismo, pelo menos. Vejamos o que se depreende do discurso de Gardner:

Muitos dos que no Brasil se intitulam brancos não merecem esse nome, porque bem poucas das famílias de longa data estabelecidas no país, têm preservado a pureza original. ${ }^{30}$

Ou seja, defende-se o princípio racista da pureza de raças. Ser branco, no caso é uma questão de merecimento e parece alguma coisa próxima à uma espécie de honra. O mesmo Gardner, no entanto, afirma:

\footnotetext{
${ }^{28}$ ESCHWEGE, 1996. p.237-238.

${ }^{29}$ GARDNER, 1975. p.23.

30 GARDNER, 1975. p.23.
} 
Não sou defensor da permanência da escravatura, desejaria, ao contrário, vê-la extirpada da face da terra - mas nunca dei ouvidos aos que figuram o Senhor de escravos no Brasil como um monstro cruel. ${ }^{31}$

Haja vista a quantidade de sangue derramando na luta entre senhores de escravos e quilombolas.

Vejamos outros exemplos:

E aqui vemos, distintamente, diante de nós, a extinção da escravatura neste magnífico Império. O negro importado, cativo, proscrito, criminoso vindo da África melhorou muito ao atravessar o mar. A raça superior que o admitiu, contudo, foi por ele altamente prejudicada, sob muitos aspectos, morais assim como físicos, principalmente indispondo-a contra todo o trabalho, e, em destaque, contra o melhor de todos os trabalhos em um país jovem: a agricultura. Onde os negros trabalham, todo trabalho se torna servil, e, em conseqüência, o povo carece do "altivo camponês, orgulho do país". ${ }^{2}$

É provável que desta visão do afro-brasileiro tenha originado a tese da indolência e da preguiça do caipira brasileiro. O que se diz é que o homem negro, em contato com o branco tenha lhe transmitido estas características. Fica evidente, neste discurso, a tese da superioridade do branco europeu - Wells, no entanto, apresenta uma posição diferente, considerando a raça negra mais trabalhadora e industriosa do que a raça branca, mas assume uma posição da qual se depreende a mesma idéia da superioridade do branco europeu. Em Wells, acredita-se que o homem negro é capaz para o trabalho braçal, não para o trabalho intelectual.

Com relação ao branco português, as construções discursivas versam sobre a superioridade da raça e em alguns momentos, associa-se a este europeu até a exigência da "pureza original".

No entanto, a se refletir sobre as palavras de Gardner citadas acima, este português é um branco degradado, na medida em que entrou em contato com o afro-brasileiro. Percebe-se no estrangeiro

${ }^{31}$ GARDNER, 1975. p.25.

32 BURTON, 1976. p.230. 
uma grande admiração pela nobreza, o que é perfeitamente corrente com as suas posições no séc. XIX.

Vejamos algumas palavras de Gobineau sobre o rei:

Nunca vi, realmente, nada mais bonito. Lá dentro, o imperador sozinho, com trajes do século XVI, de cetim branco, gola canulada, a coroa imperial na cabeça e um grande manto de veludo violeta salpicado de estrelas de ouro; e, na mão, um grande cetro de ouro com um grifo na extremidade. Ele é alto, e, com toda esta barba, estava muito bonito. ${ }^{33}$

Trata-se apenas de uma descrição que não se configura ainda numa construção discursiva, mas percebe-se aí um verdadeiro fascínio pela figura do imperador. Um pouco mais abaixo a descrição já se transforma em discurso na medida em que expressa uma posição:

Descrevendo outro dia o traje imperial do dia da abertura das câmaras, não deixei de mencionar a roupa de cetim branco e a gola canulada, mas esqueci o principal: sobre o manto de veludo, o imperador veste uma murça de plumas de tucano cor de laranja. É o símbolo essencial da soberania brasileira. Acrescento esse detalhe para ser mais exato. ${ }^{34}$

Ou seja, no discurso de Gobineau, por paradoxal que seja, a idéia da soberania nacional está ligada à coroa portuguesa.

Finalmente chegou a hora de arrematar estas reflexões. Toda a construção discursiva do estrangeiro é perpassada por uma atitude de superioridade cultural frente ao observado. Para uma mineira como eu, é extremamente singular observar a ironia com a qual Burton fala de Aleijadinho. É o caso de pensarmos no sentido da diferença. Em como esta diferença se imiscui na linguagem. As figuras de Aleijadinho, estranhamente narigudas para Burton, são a marca mais expressiva do barroco mineiro para nós. Esta estranheza diante do que é diferente, significa superioridade ou inferioridade

33 GOBINEAU apud RAEDERS, 1997. p.59.

${ }^{34}$ GOBINEAU apud RAEDERS, 1997. p.59. 
cultural entre observador e observado? Se pensarmos segundo a lógica de Parmênides, ontológica, essencialista, que se estrutura sobre uma noção de verdade, instituindo o estatuto de melhor ou pior em termos desta verdade, pode-se derivar daí esta relação. Mas se pensarmos que o diferente é apenas a expressão de um caminho outro, e que por ser outro não pode ser associado a nenhum modelo pré-estabelecido em termos de uma imposição de um dever ser, talvez cheguemos à ontologia mesma, considerando as coisas em si. Mas como os seres e as coisas se interrelacionam, mesmo esta originalidade é uma quimera. Se pensarmos que a cultura brasileira recebe a inscrição no exótico como uma forma de marginalização, talvez se deva refletir, a esta altura, na nossa inscrição em uma tradição. As nossas atitudes em relação a essa possibilidade são ambíguas. Sob certos aspectos é como se fôssemos caricatura do mundo europeu.

Vejamos como isto se expressa:

Grande desejo dos habitantes da cidade parece o de dar-se ares europeus, o que até certo ponto já acontece, em parte pelo influxo dos próprios europeus, em parte pelos muitos brasileiros que têm visitado a Europa para se educarem ou para outros fins..$^{35}$

Esta posição de simulacro do mundo europeu, que no interior do Brasil se transmuta em miséria exótica, se inscreve na memória do estrangeiro como uma encenação de um teatro de variedades marcado pela pobreza e pela dor.

Uma dor que vira resistência na atitudes de indolência e de sono. Paisagens até irreais de tanta desolação são descritas de uma forma romântica e até surrealista por Mr. Wells, em diversas passagens.

Ao fim deste estudo, acredita-se ter-se aproximado, pelo menos, do objetivo de identificar este estrangeiro que enuncia e o lugar de sua enunciação, uma vez que, o homem, em face de onde vem e de suas determinações históricas entremostra o seu lugar no

${ }^{35}$ GARDNER, 1975. p.21. 
que diz e pensa sobre os seres e as coisas. Assim sendo, mais do que fazer um estudo sociológico deste estrangeiro, este trabalho se propôs a elucida-lo através do seu próprio olhar. Acredita-se também ter-se tido a oportunidade de elucidar algo, sobre esses outros a que nos referimos nas páginas iniciais deste estudo, uma vez que o olhar desses estrangeiros incide sobre esses outros.

Mais importante até do que a configuração desse olhar é a percepção das brechas que se entremostram através dele. Esse enxergar através de norteou todo este estudo no sentido de que tentou-se o tempo todo dizer-se o não dito desses discursos.

\section{Referências Bibliográficas}

BURTON, Sir Richard Francis. Viagem do Rio de Janeiro a Morro Velho. Belo Horizonte/S. Paulo: Ed. Itatiaia/EDUSP, 1976.

ESCHWEGE, W. L. Von. Brasil, Novo Mundo. Trad. Domício Murta. Belo Horizonte: Fundação João Pinheiro, 1996.

RAEDERS, Georges. O conde de Gobineau no Brasil. Trad. Rosa F. D’Aguiar. Rio de Janeiro: Paz e Terra, 1996.

WELLS, James W. Explorando e viajando três mil milhas através do Brasil do Rio de Janeiro ao Maranhão. Trad. Míriam Ávila. Belo Horizonte: Fundação João Pinheiro, 1995.

GARDNER, George. Viagem ao interior do Brasil. São Paulo: Ed. Itatiaia, 1975.

HOLANDA, Sérgio Buarque. Visão do Paraíso. São Paulo: Ed. Brasiliana/EDUSP, 1969.

BURNS, Edward Mcnall. História da Civilização Ocidental. Trad. Lourival Gomes Machado, Lourdes Santos Machado e Leonel Vallandro. Porto Alegre: Ed. Globo, 1973.

FIORIN, José Luiz. Elementos de Análise do Discurso. São Paulo: Contexto/EDUSP. 


\section{Resumo}

Procurei flagrar a construção e desconstrução no discurso de viajantes do século XIX por ocasião da sua passagem pelo Brasil. Visando detectar as contradições desse discurso tomei como parâmetro, para esse fim, a relação homem x natureza e a relação desses estrangeiros com os homens da Terra.

Registrei a passagem da idéia de uma natureza paradisíaca para a de um locus horrendos, tanto quanto a passagem da visão de um homem cordial para uma posição um pouco mais ambígua. As ambigüidades do olhar do estrangeiro são flagradas também na visão que se tem do índio brasileiro e do homem do sertão. Fixei o meu estudo no século XIX porque preferi ver o momento da desconstrução dos discursos oficiais uma vez que estamos falando de um momento no qual já se passaram quatro séculos da descoberta.

\section{Resumen}

Procuré captar la construcción y desconstrucción en el discurso de viajeros del siglo XIX en ocasión de su paso por Brasil. Persiguiendo detectar las contradicciones de ese discurso escogí como parámetro, para ese fin, la relación hombrenaturaleza y la relación de esos extranjeros con los nativos.

Registré el paso de la idea de una naturaleza paradisíaca para la de un locus horrendus, tanto como el paso de la visión de un hombre cordial para una posición un poco más ambigua. Las ambigüedades de la visión del extranjero son captadas también en la visión que se tiene del indio brasileño y del hombre de tierra adentro. Centré mi estudio en el siglo XIX porque preferi ver el momento de la desconstrucción de los discursos oficiales una vez que estamos hablando de un momento en el cual ya pasaron cuatro siglos del descubrimento. 